\title{
The Major Molecular Causes of Familial Hypercholesterolemia
}

\author{
Phuong Kim Truong, Thuan Duc Lao and Thuy Ai Huyen Le* \\ Department of Pharmaceutical and Medical Biotechnology, Faculty of Biotechnology, \\ Ho Chi Minh City Open University, Ho Chi Minh City, Vietnam; thuy.Iha@ou.edu.vn
}

\begin{abstract}
Familial Hypercholesterolemia (FH) is a common dominant disorder of cholesterol metabolism characterized by elevated serum cholesterol level which results in increasing risk of many diseases. The major cause of FH is the loss-of-function in Low Density Lipoprotein Receptor (LDLR), Apolipoprotein B-100 (ApoB-100), Low Density Lipoprotein Receptor Adapter Protein (LDLRAP1), and Proprotein Convertase Subtilisin/Kexin type 9 (PCSK9) gene that revealed to the defects in the uptake and degradation of Low Density Lipoprotein (LDL) via the LDLR pathway. In this review, we have highlighted the molecular disorder in LDLR, ApoB-100, LDLRAP1 and PCSK gene, leading to the possible accession on early diagnosis, screening of FH based on the clinical characteristics, family history, evaluated LDL-Cholesterol levels and recently genetic testing aided, hence molecular based therapy will be applied or recommended to FH patients.
\end{abstract}

Keywords: Apolipoprotein B-100 (ApoB-100), Familial Hypercholesterolemia, Low Density Lipoprotein Receptor, Low Density Lipoprotein Receptor Adapter Protein, Proprotein Convertase Subtilisin/Kexin Type 9

\section{Introduction}

Familial hypercholesterolemia (FH; OMIN\#143890) was first described in 1930's by Carl Müller, a Norwegian clinician ${ }^{1}$. FH is a common dominant disorder of cholesterol metabolism characterized by highly elevated serum cholesterol bound to Low Density Lipoprotein (LDL) which promotes deposition of cholesterol in skin (xanthelasma), tendons (xanthomas) and coronary arteries (atheroscherosis $)^{2,3}$. In the mid 1960's, Khachadurian studied and analyzed Lebanese FH pedigrees, he concluded that FH was inherited as a monogenic autosomal codominant trait- a dominant disorder with a gene-dosage effect ${ }^{2,4}$. According to FH Foundation statistics, the frequency of $\mathrm{FH}$ in worldwide population is about 1 of $250-500$ people. Many factors affect the manifestation of FH including age, gender, diet, and genetic disorders, such as a mutation in LDLR (Low Density Lipoprotein Receptor) (Chromosome 19), APOB-100 (Apolipoprotein B-100)
(Chromosome 24). This review will describe the FH disease and the way in which the genetic basic of FH disorder, leading to the elucidation of LDL-receptor pathway, and how defects in different genes resulted in FH disease.

\section{Genetic Counseling}

$\mathrm{FH}$ is one of the most frequent monogenetic disorder, and inherited in an autosomal dominant hypercholesterolemia, meant that the affected parent with this disorder has $50 \%$ opportunity of passing the gene to each of his or her children. Because of the dominant, the inherited child will have this disorder (Figure 1). This disorder occurs in two clinical manifestations: Heterozygous Familial Hypercholesterolemia ( $\mathrm{HeFH}$ ) meant that the FH gene was inherited from one parent, and more severe Homozygous Familial Hypercholesterolemia $(\mathrm{HoFH})$ the $\mathrm{FH}$ gene was inherited from each of parents ${ }^{1}$. Recently, the prevalence of $\mathrm{HeFH}$ has been estimated to be about 1:250-500

${ }^{*}$ Author for correspondence 
making it were suspected to be more frequent, while the prevalence of $\mathrm{HoFH}$ has been reported in 1:1 million ${ }^{7}$. FH could be caused by the mutations in four known genes. About $85 \%$ to $95 \%$ of $\mathrm{FH}$ cases are due to the inherited mutations in LDLR gene leading to functional reductions in the capacity to clear LDL Cholesterol (LDL-C) from circulation has been identified ${ }^{8,9}$. Less commonly, the mutations in Apolipoprotein B (ApoB) gene that encoded protein recognizes LDL-C and leading to binding of LDL-C to the LDL receptor; and Proprotein Convertase Subtilisin/Kexin type 9 (PCSK9) gene that mediates the degradation of the LDL receptor and Low Density Lipoprotein Receptor Adaptor Protein 1 (LDLRAP), a serine protease that degrades or destroys the LDL receptor $^{10-14}$ (Figure 2).

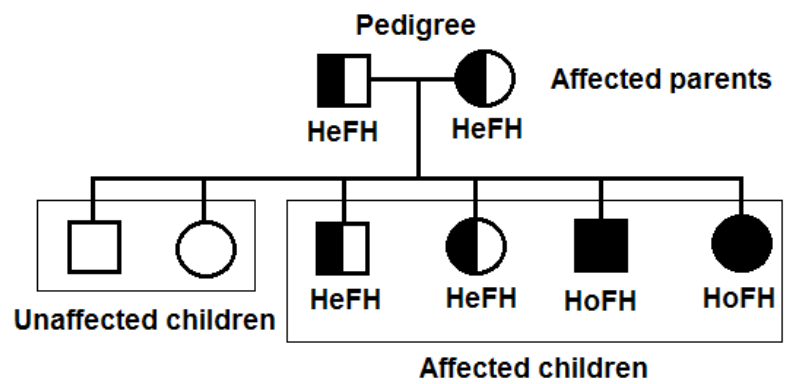

Figure 1. Inherited $\mathrm{HeFH}$ and $\mathrm{HoFH}$.

\subsection{LDLR Gene}

The Low-Density Lipoprotein Receptor (LDLR), originally identified by Brown and Goldstein in 1973 during their research for the molecular basis of $\mathrm{FH}$, is the cell surface receptor that plays an important role in cholesterol homeostasis that mediates the specific uptake of LDL from the circulation and transfer into cells via endocytosis. Brown and Goldstein showed that the mutation in LDLR was the cause of monogenic $\mathrm{FH}^{15}$.

The LDLR gene is localized at 19p13.1-p13.3 spans $45 \mathrm{~kb}$, includes 18 exons, encodes a glycoprotein of 839 amino acids that functions in cholesterol homeostasis ${ }^{16,17}$. Till now, the six functional domains of the LDLR and the exons of LDLR gene is well understood (Figure 3).

Mutation in gene coding LDLR is the most common genetic cause of $\mathrm{FH}$, to date, more than 1,600 mutations (including missense, nonsense, deletion, and insertion types) have been reported ${ }^{8,9,18}$. Till now, a large of mutations have been catalogued from around the world on many websites, such as the LOVD database (Leiden Open (source) Variation Database: http://www.ucl.ac.uk/ ldlr/LOVDv.1.1.0/); UMD LSDBs (UMD Locus Specific Databse: http://www.umd.be/LDLR), etc. According to LOVD database, total of 1741 variants of LDLR gene have been reported including substitutions, insertions, dele-

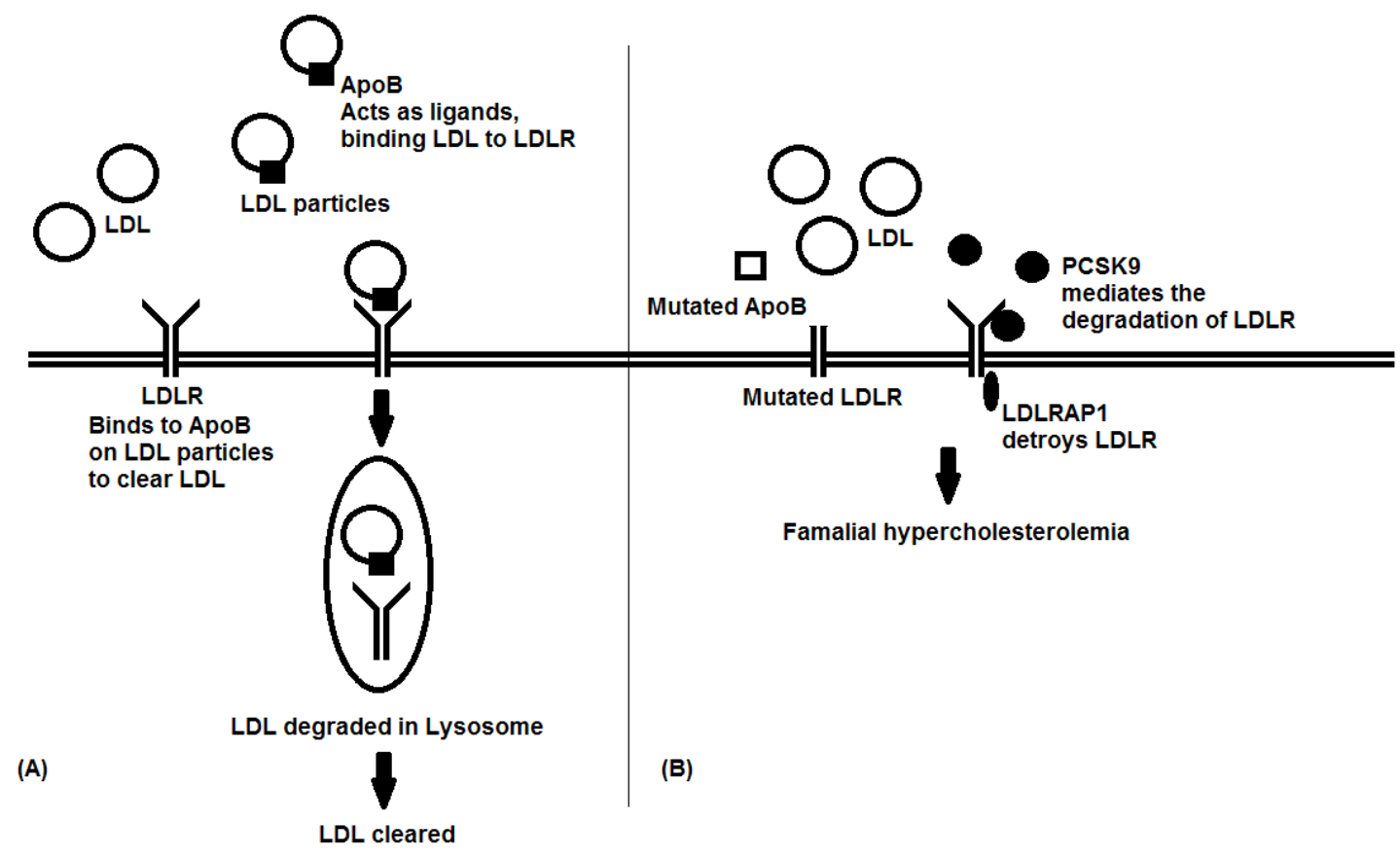

Figure 2. (A) The LDL-R pathway for uptake and degrade LDL. (B) FH is caused by four known genes. 


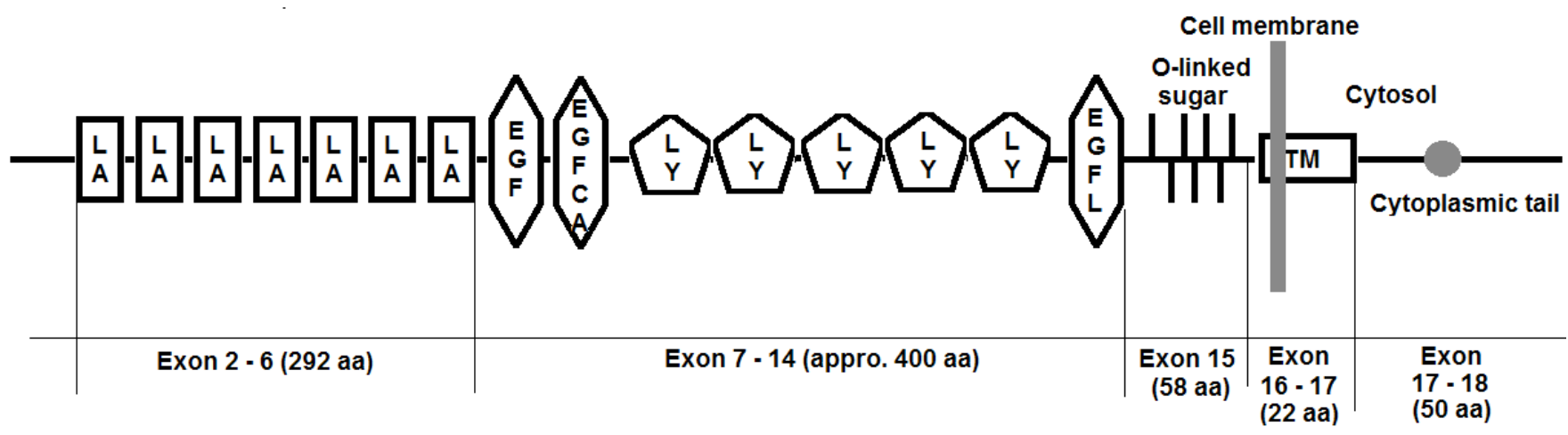

Figure 3. Domains organization of LDLR (Adapted from Human Protein Reference Database: http://www.hprd.org/). LA: Low-density lipoprotein receptor domain class A; EGF: Epidermal Growth factor-like domain; EGFCA: Calcium-binding EGF-like domain; LY: Low-density lipoprotein-receptor YWTD domain; EGFL: EGF domain, unclassified subfamily; TM: Transmembrane domain.

tions, duplications, etc. in the literature. Majority of these variants are nucleotide substitutions, counting for $73.5 \%$ (1280/1741) including missense substitutions: $72.9 \%$ (933/1280), nonsense substitutions: $13.8 \%$ (176/1280), other substitutions: $13.4 \%$ (171/1280). Mutations in LDLR gene are distributed along the full gene length, however, a high frequency of mutation in exon-4 coding central region of the ligand-binding domain have been reported $^{19}$ (Figure 4). It could be explained that Exon 4 encodes three of seven cysteine-rich ligand binding repeats of the LDLR that plays an essential role which is required for LDL binding via Apolipoprotein B in receptor binding activity ${ }^{20}$. Therefore, mutations in this region leading to more severe $\mathrm{FH}$ than others. Based on the

\begin{tabular}{|c|c|c|}
\hline \multirow[t]{2}{*}{ Signal sequence } & Exon 01 (79): & $4.5 \%$ \\
\hline & |Exon 02 (82): & $4.7 \%$ \\
\hline \multirow{3}{*}{ Ligands binding } & Exon 03 (125): & $7.2 \%$ \\
\hline & Exon 04 (339): & $19.5 \%$ \\
\hline & Exon 05 (71): & $4.1 \%$ \\
\hline \multirow{9}{*}{ EGF precusor homology } & Exon 06 (91): & $5.2 \%$ \\
\hline & Exon 07 (105): & $6 \%$ \\
\hline & Exon 08 (106): & $6.1 \%$ \\
\hline & Exon 09 (145): & $8.3 \%$ \\
\hline & Exon 10 (110): & $6.3 \%$ \\
\hline & Exon 11 (77): & $4.4 \%$ \\
\hline & Exon 12 (96): & $5.5 \%$ \\
\hline & Exon 13 (72): & $4.1 \%$ \\
\hline & | Exon 14 (100): & $5.7 \%$ \\
\hline \multirow{3}{*}{ Membrane spanning } & Exon 15 (41): & $2.4 \%$ \\
\hline & Exon 16 (38): & $2.2 \%$ \\
\hline & Exon $17(60)$ : & $3.4 \%$ \\
\hline Cytoplasmic tail & Exon $18(4)$ : & $0.2 \%$ \\
\hline
\end{tabular}

Figure 4. Sequence variations in per exon of LDLR gene (Adapted from LOVD database). defects of LDLR, five major classes have been identified (Table 2) $)^{9,21,22}$.

\subsection{ApoB Gene}

In contrast to LDLR gene, mutation in Apolipoprotein B-100 gene (ApoB, \#MIN 107730) is also associated with FH phenotype, but it is less common $(<8 \%)^{2,3,10,24}$. The clinical phenotype $\mathrm{FH}$ associated $\mathrm{ApoB}$ gene mutations is defined as "Familial Defective Apolipoprotein B-100" (FDB). The ApoBgene is localized at 2p24.1 and consists 28 introns and 29 exons that codes for the protein component of LDL particles, plays a central role in human lipoprotein metabolism ${ }^{24,25}$. In human plasma, $A$ poB is existed in two different forms: ApoB-48and ApoB-10025. ApoB (2152 amino acids) is produced by the intestine, and identical to the amino-terminal $48 \%$ of ApoB-100, whereas ApoB-100 (4536 amino acids) is produced by liver. ApoB100 is the protein component responsible for the cellular recognition and catabolism of LDL via the LDLR pathway. Therefore, ApoB-100 mediates the binding of LDL to LDLR, leading the clearance of LDL particles (Figure 2(a)). ApoB-100 has defined as five structural domains termed as $\beta \alpha_{1}, \beta_{1}, \alpha_{2}, \beta_{2}$, and $\alpha_{3}(\beta$ indicates $\beta$-sheet; $\alpha$ indicates $\alpha$-helix structure) (Figure 5). Mutations in the ApoB-100 will drastically alter its functional activity leading to a decrease in its binding to LDLR, resulting in $\mathrm{FH}^{3}$. In contrast to LDLR, small mutations, such as R3500Q, R3500W, R3531C, and R3480W have been found only in residues 3130-3630 which are important for the binding of ApoB-100 to the LDL receptor ${ }^{26-29}$. According to 
Table 1. Criteria for diagnosis of familial hypercholesterolemia based on The Dutch Lipid Clinic criteria

\begin{tabular}{|c|c|c|}
\hline Criteria & Score & Patient score \\
\hline \multicolumn{3}{|l|}{ LDL-cholesterol (mmol/L): } \\
\hline $4.0-4.9(\sim 155-189 \mathrm{mg} / \mathrm{dl})$ & 1 & \\
\hline $5.0-6.4(\sim 190-249 \mathrm{mg} / \mathrm{dl})$ & 3 & \\
\hline $6.5-8.4(\sim 250-329 \mathrm{mg} / \mathrm{ml})$ & 5 & \\
\hline$\geq 8.5(\sim 330 \mathrm{mg} / \mathrm{ml})$ & 8 & \\
\hline \multicolumn{3}{|l|}{ Physical examination: } \\
\hline Tendinous xanthamata & 6 & \\
\hline Acruscornealis before 45 years old & 4 & \\
\hline \multicolumn{3}{|l|}{ Clinical history: } \\
\hline Patients with premature coronary artery disease (men aged < 55 years, women aged <60 years) & 2 & \\
\hline $\begin{array}{l}\text { Patients with premature cerebral or peripheral vascular disease (men aged }<55 \text { years, women aged }<60 \\
\text { years) }\end{array}$ & 1 & \\
\hline \multicolumn{3}{|l|}{ Family history: } \\
\hline $\begin{array}{l}\text { First degree relative with known premature coronary and/or vascular disease (men aged }<55 \text { years, } \\
\text { women aged }<60 \text { years), OR } \\
\text { First degree relative with known LDL-cholesterol above the } 95^{\text {th }} \text { percentile for age and gender }\end{array}$ & 1 & \\
\hline $\begin{array}{l}\text { First degree relative with tendinous xanthomata and/or arcus cornealis, OR } \\
\text { Children aged }<18 \text { years with LDL-cholesterol above the } 95^{\text {th }} \text { percentile for age and gender }\end{array}$ & 2 & \\
\hline \multicolumn{3}{|l|}{ Total score } \\
\hline \multicolumn{3}{|l|}{ Diagnosis: } \\
\hline \multicolumn{3}{|l|}{ Definite FH: Total score $>8$} \\
\hline \multicolumn{3}{|l|}{ Probable FH: Total score $6-8$} \\
\hline \multicolumn{3}{|l|}{ Possible FH: Total score 3 - 5} \\
\hline Unlikely FH: Total score $<3$ & & \\
\hline
\end{tabular}

Table 2. The five major LDLR defects

Class 1: LDL receptor is not synthesized at all.

Class 2: LDL receptor is not properly transported from the endoplasmic reticulum to the Golgi apparatus for expression on the cell surface.

Class 3: LDL receptor does not properly bind LDL on the cell surface because of a defect in either Apolipoprotein (APO) B-100 (R3500Q) or in the LDL receptor.

Class 4: IV: LDL receptor bound to LDL does not properly cluster in Clathrin-coated pits for receptor-mediated endocytosis. Class 5: LDL receptor is not recycled back to the cell surface

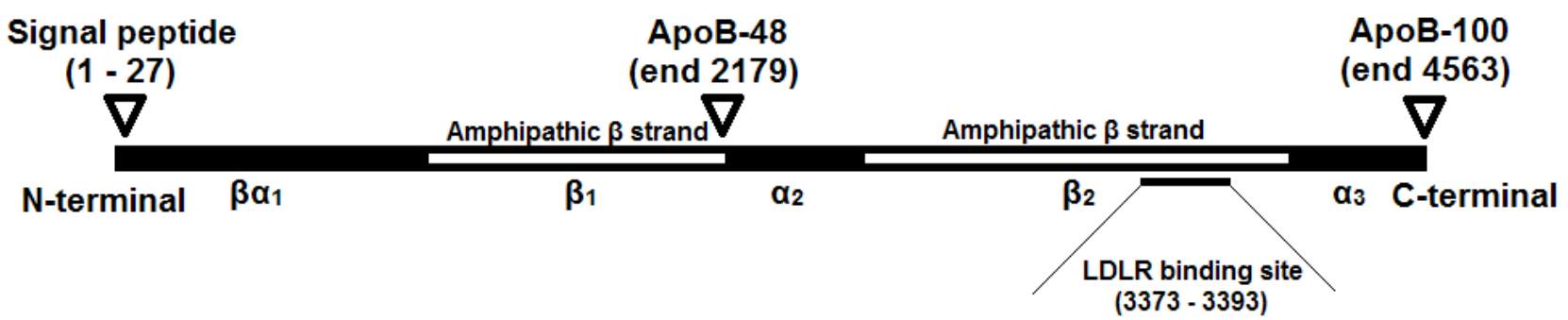

Figure 5. Schematic diagram of ApoB-1100. 
the study of Borén et al. (2001), they investigated that the molecular mechanism of the normal receptor binding in ApoB-100 depends on the interaction of Arginine 3500 (R3500) and Tryptophan 4369 (W4369). The interaction between R3500 and W4369 is important and essential for the correct folding of the carboxyl terminal of ApoB-100 which permits normal interaction between LDL and LDLR. Additionally, W4369 interacts not only the R3500, but also with R3480 and R3531. Therefore, the mutation in those sites could disrupt the binding of LDL to its receptor leading to FH. They proposed that Arginine-Tryptophan interactions are crucial during the conversion of VLDL to LDL for positioning ApoB-100 carboxyl tail which functions as a modulator element that inhibits VLDL from interacting with LDL receptor to permit ApoB-100 on LDL to bind normally to the receptor. The disrupted folding process gives rise to the forming of FDB. The mutations in ApoB-100 have been found to be linked to the defective LDLR binding and hypercholesterolemia: Exon 26: R3500Q, R3500W, R3480W; Exon 29: W4369Y $\mathrm{Y}^{8,9,28-30}$. The most common mutation in ApoB100 is R3500Q which leads to the autosomal dominantly inherited clinical disorder $\mathrm{FDB}^{8,9}$.

\subsection{LDLRAP1 Gene}

LDLRAP1 protein encoded by LDLRAP1 gene also known as ARH is mapped to chromosome 1p35, includes 9 exons, encoded a $32-\mathrm{kDa}$ endocytic adaptor protein of 308 -amino acid protein that interacts with the cytoplasmic tail of LDLR, results in LDLR endocytosis ${ }^{31,32}$. Mutation in gene coding LDLRAP1 has been reported to be associated with the Autosomal Recessive Hypercholesterolemia (ARH) which is considered as an extremely rare inherited hypercholesterolemia $^{33,34}$. LDLRAP1 protein contains the conversed Phosphotyrosine-Binding (PTB) domain, and reported to function as an accessory adaptor protein which binds the consensus sequence NPXY presents in the cytoplasmic domains of several cell-surface proteins, and mediates its cellular internalization via the chathrinmachinery $^{31}$. Up to now, there are few published documents about the mutation on LDLRAP1 as well as the clinical characteristics of LDLRAP1 heterozygous mutations carriers due to the rarity of this disorder. The phenotype of ARH is similar to that of patients with HoFH caused by mutated LDLR, but it is somewhat milder in terms of serum total cholesterol and LDL cholesterol levels, and shows the better response to treatment with lipidlowering drugs or without LDL apheresis ${ }^{33}$. According to the LOVD database (Leiden Open (source) Variation Database: http://www.ucl.ac.uk/ldlr/LOVDv.1.1.0/), a high frequency of mutation in exon-1 have been reported (Figure 6). In the study of Gracia et al., they identified six mutations in ARH, including 1 frameshift was found in homozygosity in the Sardinian families, 1 nonsense mutation was found in the Lebanese family, and other mutations were missense resulting in the high plasma LDL level ${ }^{31}$. Notably, all the affected individuals were homologous for a frameshift mutation at nucleotide 432 of LDLRAP1 resulting appearance of termination codon at residue 170 leading to the coronary artery disease with 8 relatives in this family died at an age of less than 33 years old ${ }^{31}$.

$\begin{array}{ll}\text { Exon } 01(14): & 35.9 \% \\ \text { Exon 02 (1): } & 2.6 \% \\ \text { Exon 03 (1): } & 2.6 \% \\ \text { Exon 04 (6): } & 15.4 \% \\ \text { Exon 05 (2): } & 5.1 \% \\ \text { Exon 06 (8): } & 20.5 \% \\ \text { Exon 07 (6): } & 15.4 \% \\ \text { Exon 08 (1): } & 2.6 \% \\ \text { Exon 09 (0): } & 0 \%\end{array}$

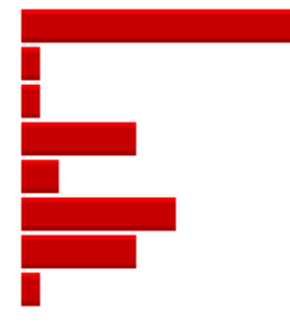

Figure 6. Sequence variations in per exon of LDLRAP1 gene (Adapted from LOVD database).

\subsection{PCSK9 Gene}

The heterozygous mutation on PCSK9 Proprotein Convertase Subtilisin/Kexin type 9 located at 1p32 contains 12 exons, first found in 2003 by Abifadelet al., have since shown to be associated with $\mathrm{FH}^{12}$. This is the least common cause of $\mathrm{FH}$ accounting less than 5\% of cases ${ }^{8}$. Abifadel et al., reported that PCSK9 cDNA also known as Neural Apoptosis-Regulated Convertase-1 (NARC1), yields 3.617 bps and encodes a protein of 692 amino acids, that mediates the degradation of the LDLR ${ }^{12}$. PCSK9 is belonged to the subtilisin family of kexin-like proconvertases has defined as three structural domains, including signal sequence, prodomain, catalytic domain followed by C-terminal (Figure 7).

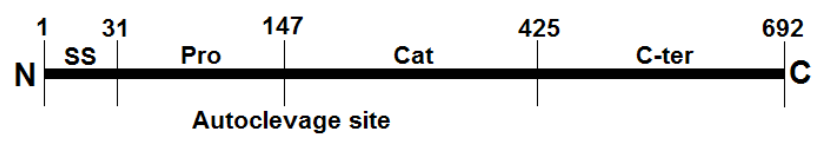

Figure 7. Schematic diagram of PCSK9. 
According to LOVD database (Leiden Open (source) Variation Database, total of 163 variants have been reported, and a high frequency of mutation was observed in exon 1 (Figure 8). Functional defects have been studied to be associated with two forms of function mutations of PCSK9 in human, including loss-of-function and gainof-function mutation ${ }^{35}$. Gain-of-function mutation in PCSK9, including S127R, D129N (in prodomain); R215H, F216L, R128S (in catalytic domain); R469W, R496W (in C-terminal) degrades the LDLR in the liver resulting in increase of plasma LDL level and susceptibility to coronary heart disease ${ }^{12}$, whereas the loss-of-function mutations, such as R46L, $\Delta \mathrm{R} 97, \mathrm{G} 106 \mathrm{R}, \mathrm{Y} 142 \mathrm{X}$ (in prodomain); L253F (in catalytic domain); A443T, C679X(in C-terminal), lead to the reduction of plasma levels of LDL cholesterol via reduces PCSK9 mediated degradation ${ }^{35,36}$. Therefore, PCSK9 has become an insight into the discovery of new target drug for cholesterol-lowering therapy ${ }^{2,47}$.

\begin{tabular}{|c|c|}
\hline Exon 01 (34): & $20.9 \%$ \\
\hline Exon $02(17)$ : & $10.4 \%$ \\
\hline Exon 03 (5): & $3.1 \%$ \\
\hline Exon 04 (14): & $8.6 \%$ \\
\hline Exon 05 (22): & $13.5 \%$ \\
\hline Exon $06(4)$ : & $2.5 \%$ \\
\hline Exon $07(7)$ : & $4.3 \%$ \\
\hline Exon 08 (12): & $7.4 \%$ \\
\hline Exon 09 (18): & $11 \%$ \\
\hline Exon $10(9)$ : & $5.5 \%$ \\
\hline Exon 11 (5): & $3.1 \%$ \\
\hline Exon $12(16)$ : & $9.8 \%$ \\
\hline
\end{tabular}

Figure 8. Sequence variations in per exon of PCSK9 gene (Adapted from LOVD database).

\section{General and Genetic Screening of $\mathrm{FH}$}

According to universal criteria for FH screening based on the fasting LDL cholesterol or non-high density lipoprotein (non-HDL) cholesterol levels, which are at or above the following: Adults ( $\geq 20$ years): LDL cholesterol $\geq 190$ $\mathrm{mg} / \mathrm{dL}$ or non-HDL cholesterol $\geq 220 \mathrm{mg} / \mathrm{dL}$; Children, adolescents and young adults ( $<20$ years): LDL cholesterol $\geq 160 \mathrm{mg} / \mathrm{dL}$ or non-HDL cholesterol $\geq 190 \mathrm{mg} / \mathrm{dL}^{5}$.

The MEDPED (Make Early Diagnosis to Prevent Early Deaths) criteria from The Dutch Lipid Clinic criteria, which takes into consideration of cholesterol concentration, clinical characteristics, genetic disorders and familial history, are validated diagnosis of $\mathrm{FH}$ by the subsequent score categorizes patients (Table 1$)^{6}$.
To our knowledge, the early detection of FH gene mutation carrier allows primary prevention of $\mathrm{FH}$ and coronary heart disease, thus, it is essential for simple diagnosis tools for the genetics analysis. The detection of mutations in the LDLR, ApoB, LDLRAP1 or PCSK9 has been considered to be the criteria for the diagnosis of monogenic causes of FH. For the detection of mutations of FH gene, several genetic methods have been established, including sequencing, Single-Strand Conformation Polymorphism (SSCP) analysis, Denaturing Gradient Gel Electrophoresis (DGGE), melting analysis, Denaturing High Performance Liquid Chromatography (DHPLC), Multiplex Probe Amplification (MLPA), etc. Recent approaches include target exon sequencing, Array-based resequencing, or Next Generation Sequencing (NGS), Whole Genome Sequencing (WGS), have been identified in a number of numerous mutations on FH-related genes.

\section{Novel Therapies for FH}

In current therapies a number of guidelines for $\mathrm{FH}$ therapies have been reported in order to reduce the LDL-C levels below 2.5 or $1.8 \mathrm{mmol} / \mathrm{L}$ without increased risk of Cardiovascular disease ${ }^{37}$. According to NLA recommendations, the NCEP ATP III guidelines, and the NICE guidelines, statins, also known as HMG-CoA (3-hydroxy-3-methylglutaryl-coenzyme A) reductase inhibitors therapy was suggested to be the corner-stone and first-line therapy for FH patients. Statins, including lovastatin, simvastatin, pravastatin, atorvastatin, fluvastatin, pitavastatin, rosuvastatin, supported by FDA, act by competitively block the HMG-CoA reductase in the liver, the enzyme that converts HMG-CoA into mevalonic acid, a cholesterol precursor, then making for cholesterol (Figure 9) ${ }^{38,39}$. Other different kinds of medicines to control cholesterol includes Bile acid sequestrants, Fibrates, Niacin, Cholesterol absorption inhibitors, Omega-3 fatty acid, etc.

Over the past few years, many studies have been afforded led to the emergence of a number of novel therapies for lowering LDL-C levels based on the genetic disorders such as PCSK9, ApoB-100 served as potential therapeutic targets. Mipomirsen (FDA approval) is an antisense oligonucleotide of 20 nucleotides that targets ApoB-100 in liver for treatment of HoFH. Mipomersen acts by hybridizing within the coding region of apoB-100 mRNA resulting in activation of RNase $\mathrm{H}$, an enzyme 


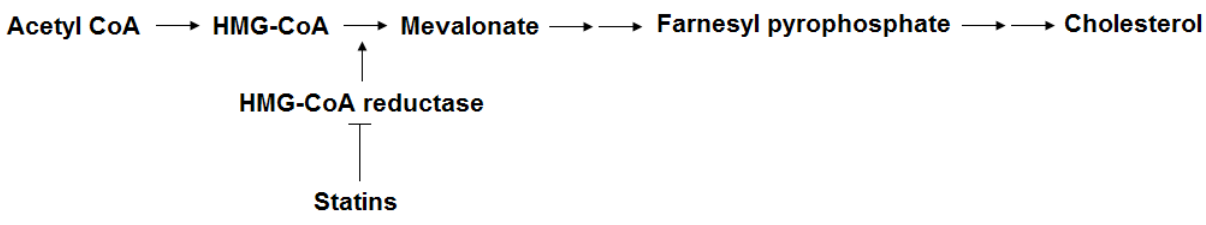

Figure 9. Inhibition of the cholesterol biosynthesis pathway acted by statins.

that catalyzes the RNA cleavage, and selective causes the degradation of ApoB-100 mRNA. This result inhibits the cessation of $A p o B$ protein translation and thereby the production of atherogenic lipids, includes LDL, VLDL, and lipoprotein is decreased ${ }^{40,41}$. The MTP (Microsomal Triglyceride Transfer) protein that is required for the assembly and secretion of VLD-Lipoprotein by the liver ${ }^{42}$. After VLDL is secreted, VLDL is converted to LDL. Lomitapide, developed by Aegerion Pharmaceuticals, approval by US FDA, used as an orphan drug in treatment of HoFH blocks the MTP activities resulting in reduction of plasma LDLC levels ${ }^{43}$. PCSK9i (PCSK9 inhibitor), the kind of monoclonal antibodies, a new therapeutic class represents a novel and promising approach to reducing of LDL-C levels by using a mechanism at LDLR level ${ }^{44}$. PCSK9i binds to PCSK9, resulting in inhibits the binding of PCSK9 to LDLR, thereby blunting PCSK9-mediated LDLR degradation, LDL-C levels can be lowered 50\%$60 \%$ above that achieved by statin therapy alone ${ }^{45,46}$.

\section{Conclusion}

$\mathrm{FH}$ is an inherited disorder characterized by a high concentration of serum LDL cholesterol, which has been identified to be significant to the cardiovascular disease. FH is an autosomal, dominant genetic disorder associated with the mutation in FH-related genes, including LDLR, ApoB-100, LDLRAP1 and PCSK1 gene. Screening typical by the evaluation of the level of Cholesterol as well as using The Dutch Lipid Clinic criteria, confirmed by the genetic analysis of FH-related genes, give the well diagnosis of FH. The early identification and initial of treatment is paramount to make a huge impact on the prevention of $\mathrm{CHD}$ and related detrimental squeal.

\section{Acknowledgement}

We wish to express our thanks to the research project sponsored by Ho Chi Minh City Open University, Ho Chi Minh City, Vietnam.

\section{References}

1. Najam O, Ray KK. Familial hypercholesterolemia: A review of the natural history, diagnosis, and management. Cardiol Ther. 2015; 4(1):25-38. Crossref PMid:25769531 PMCid:PMC4472649

2. Soutar AK, Naoumova RP. Mechanisms of disease: Genetic causes of familial hypercholesterolemia. Nat Clin Pract Cardiovasc Med. 2007; 4(4):214-25. Crossref PMid:17380167

3. Farrokhi E, Shayesteh F, Asadi Mobarakeh S, Roghani Dehkordi F, Ghatreh Samani K, Hashemzadeh Chaleshtori M. Molecular characterization of Iranian patients with possible familial hypercholesterolemia. Indian J Clin Biochem. 2011; 26(3):244-8. Crossref PMid:22754187 PMCid:PMC3162949

4. Khachadurian AK. The inheritance of essential Familial Hypercholesterolemia. Am J Med. 1964; 37:402-7. Crossref

5. Williams RR, Hunt SC, Schumacher MC, Hegele RA, Leppert MF, Ludwig EH, et al. Diagnosing heterozygous familial hypercholesterolemia using new practical criteria validated by molecular genetics. Am J Cardiol. 1993; 72(2):171-6. Crossref

6. Séguro F, Bongard V, Bérard E, Taraszkiewicz D, Ruidavets JB, Ferrières J. Dutch lipid clinic network low-density lipoprotein cholesterol criteria are associated with long-term mortality in the general population. Arch Cardiovasc Dis. 2015; 108(10):511-8. Crossref PMid:26073227

7. Goldstein JL, Brown MS. Molecular medicine. The cholesterol quartet. Science. 2001; 292(5520):1310-2. Crossref

8. Varret M, Abifadel M, Rabès JP, Boileau C. Genetic heterogeneity of autosomal dominant hypercholesterolemia. Clin Genet. 2008; 73(1):1-13. Crossref PMid:18028451

9. Hopkins PN, Toth PP, Ballantyne CM, Rader DJ. National lipid association expert panel on familial hypercholesterolemia. Familial hypercholesterolemias: Prevalence, genetics, diagnosis and screening recommendations from the National Lipid Association Expert Panel on Familial Hypercholesterolemia. J Clin Lipidol. 2011(3 Suppl); 5:S917. Crossref PMid:21600530

10. Innerarity $\mathrm{TL}$, Mahley RW, Weisgraber $\mathrm{KH}$, Bersot TP, Krauss RM, Vega GL, et al. Familial defective Apolipoprotein B-100: a mutation of apolipoprotein B that 
causes hypercholesterolemia. J Lipid Res. 1990; 31(8):133749. PMid:2280177

11. Walldius G, Jungner I, Holme I, Aastveit AH, Kolar W, Steiner E. High apolipoprotein B, low apolipoprotein A-I, and improvement in the prediction of fatal myocardial infarction (AMORIS study): a prospective study. Lancet. 2001; 358(9298):2026-33. Crossref

12. Abifadel $M$, Varret $M$, Rabès JP, Allard D, Ouguerram $\mathrm{K}$, Devillers $\mathrm{M}$, et al. Mutations in PCSK9 cause autosomal dominant hypercholesterolemia. Nat Genet. 2003; 34(2):154-6. Crossref PMid:12730697

13. 13. Banaszak LJ, Ranatunga WK. The assembly of apoBcontaining lipoproteins: A structural biology point of view. Ann Med. 2008; 40(4):253-67. Crossref PMid:18428019

14. Horton JD, Cohen JC, Hobbs HH. PCSK9: A convertase that coordinates LDL catabolism. J Lipid Res. 2009; 50(Suppl):S172-7. Crossref PMid:19020338 PMCid:PMC2674748

15. Brown MS, Goldstein JL. Familial hypercholesterolemia: Defective binding of lipoproteins to cultured fibroblasts associated with impaired regulation of 3-hydroxy-3-methylglutaryl coenzyme A reductase activity. Proc Natl Acad Sci U S A. 1974; 71(3):788-92. Crossref

16. Francke U, Brown MS, Goldstein JL. Assignment of the human gene for the low density lipoprotein receptor to chromosome 19: synteny of a receptor, a ligand, and a genetic disease. Proc Natl Acad Sci U S A. 1984; 81(9):282630. Crossref PMid:6326146 PMCid:PMC345163

17. Lindgren V, Luskey KL, Russell DW, Francke U. Human genes involved in cholesterol metabolism: chromosomal mapping of the loci for the low density lipoprotein receptor and 3-hydroxy-3-methylglutaryl-coenzyme A reductase with cDNA probes. Proc Natl Acad Sci U S A. 1985; 82(24):856771. Crossref PMid:3866240 PMCid:PMC390958

18. Usifo E, Leigh SE, Whittall RA, Lench N, Taylor A, Yeats $\mathrm{C}$, et al. Low-density lipoprotein receptor gene familial hypercholesterolemia variant database: update and pathological assessment. Ann Hum Genet. 2012; 76(5):387-401. Crossref PMid:22881376

19. Arráiz N, Bermúdez V, Rondon N, Reyes F, Borjas L, Solís E, et al. Novel mutations identification in exon 4 of LDLR gene in patients with moderate hypercholesterolemia in a Venezuelan population. Am J Ther. 2010; 17(3):325-9. Crossref PMid:20019594

20. Neff D, Ruschitzka F, Hersberger M, Enseleit F, Hürlimann D, Noll G, et al. Detection of a novel exon 4 low-density lipoprotein receptor gene deletion in a swiss family with severe familial hypercholesterolemia. Clin Chem Lab Med. 2003; 41(3):266-71. Crossref PMid:12705331

21. Hobbs HH, Russell DW, Brown MS, Goldstein JL. The LDL receptor locus in familial hypercholesterolemia: mutational analysis of a membrane protein. Annu Rev Genet. 1990; 24:133-70. Crossref PMid:2088165

22. Hobbs HH, Brown MS, Goldstein JL. Molecular genetics of the LDL receptor gene in familial hypercholesterolemia. Hum Mutat. 1992; 1:445-66. Crossref PMid:1301956

23. Varghese MJ. Familial hypercholesterolemia: A review. Annals of Pediatric Cardiology. 2014; 7(2):107-17. Crossref PMid:24987256 PMCid:PMC4070199

24. Knott TJ, Rall SC Jr, Innerarity TL, Jacobson SF, Urdea MS, Levy-Wilson B, et al. Human apolipoprotein B: Structure of carboxyl-terminal domains, sites of gene expression, and chromosomal localization. Science. 1985; 230(4721):3743. Crossref PMid:2994225

25. Law SW, Lackner KJ, Hospattankar AV, Anchors JM, Sakaguchi AY, Naylor SL, et al. Human apolipoprotein B-100: cloning, analysis of liver mRNA, and assignment of the gene to chromosome 2. Proc Natl Acad Sci U S A. 1985; 82(24):8340-4. Crossref PMid:3001697 PMCid:PMC390911

26. Soria LF, Ludwig EH, Clarke HR, Vega GL, Grundy SM, Mc Carthy BJ. Association between a specific apolipoprotein B mutation and familial defective apolipoprotein B-100. Proc Natl Acad Sci U S A. 1989; 86(2):587-91. Crossref PMid:2563166 PMCid:PMC286517

27. Dunning AM, Houlston R, Frostegård J, Revill J, Nilsson J, Hamsten A, et al. Genetic evidence that the putative receptor binding domain of apolipoprotein B (residues 3130 to 3630 ) is not the only region of the protein involved in interaction with the low density lipoprotein receptor. Biochim Biophys Acta. 1991; 1096(3):231-7. Crossref

28. Gaffney D, Reid JM, Cameron IM, Vass K, Caslake MJ, Shepherd J, et al. Independent mutations at codon 3500 of the apolipoprotein B gene are associated with hyperlipidemia. Arterioscler Thromb Vasc Biol. 1995; 15(8):1025-9. Crossref PMid:7627691

29. Pullinger CR, Hennessy LK, Chatterton JE, Liu W, Love JA, Mendel CM, et al. Familial ligand-defective apolipoprotein B. Identification of a new mutation that decreases LDL receptor binding affinity. J Clin Invest. 1995; 95(3):1225-34. Crossref PMid:7883971 PMCid:PMC441461

30. Borén J, Ekström U, Agren B, Nilsson-Ehle P, Innerarity TL. The molecular mechanism for the genetic disorder familial defective apolipoprotein B100. J Biol Chem. 2001; 276(12):9214-8. Crossref PMid:11115503

31. Garcia CK, Wilund K, Arca M, Zuliani G, Fellin R, Maioli $\mathrm{M}$, et al. Autosomal recessive hypercholesterolemia caused by mutations in a putative LDL receptor adaptor protein. Science. 2001; 292(5520):1394-8. Crossref PMid:11326085

32. Sun XM, Patel DD, Acosta JC, Gil J, Soutar AK. Premature senescence in cells from patients with Autosomal Recessive 
Hypercholesterolemia (ARH): Evidence for a role for ARH in mitosis. Arterioscler ThrombVasc Biol. 2011; 31(10):2270-7. Crossref PMid:21778424

33. Soutar AK, Naoumova RP. Autosomal Recessive Hypercholesterolemia. Semin Vasc Med. 2004; 4(3):241-8. Crossref PMid:15630633

34. Tada H, Kawashiri MA, Ohtani R, Noguchi T, Nakanishi C, Konno T, et al. A novel type of familial hypercholesterolemia: Double heterozygous mutations in LDL receptor and LDL receptor adaptor protein 1 gene. Atherosclerosis. 2011; 219(2):663-6. Crossref PMid:21872251

35. Horton JD, Cohen JC, Hobbs HH. Molecular biology of PCSK9: its role in LDL metabolism. Trends Biochem Sci. 2007; 32(2):71-7. Crossref PMid:17215125 PMCid:PMC2711871

36. Peterson AS, Fong LG, Young SG. PCSK9 function and physiology. J Lipid Res. 2008; 49(6):1152-6. Crossref PMid:18375913 PMCid:PMC2386899

37. Hartgers ML, Ray KK, Hovingh GK. New approaches in detection and treatment of familial hypercholesterolemia. Curr Cardiol Rep. 2015; 17(12):109. Crossref PMid:26482752 PMCid:PMC4611021

38. Stancu C, Sima A. Statins: mechanism of action and effects. J Cell Mol Med. 2001; 5(4):378-87. Crossref PMid:12067471

39. Endo A. A historical perspective on the discovery of statins. Proc Jpn Acad Ser B Phys Biol Sci. 2010; 86(5):484-93. Crossref PMid:20467214 PMCid:PMC3108295

40. Wong E, Goldberg T. Mipomersen (kynamro): A novel antisense oligonucleotide inhibitor for the management of homozygous familial hypercholesterolemia. P T. 2014; 39(2):119-22.

41. Agarwala A, Jones P, Nambi V. The role of antisense oligonucleotide therapy in patients with familial hypercholesterolemia: risks, benefits, and management recommendations. Curr Atheroscler Rep. 2015; 17(1):467. Crossref PMid:25398643

42. Jamil H, Dickson JK Jr, Chu CH, Lago MW, Rinehart JK, Biller SA, et al. Microsomal triglyceride transfer protein. Specificity of lipid binding and transport. J Biol Chem. 1995; 270(12):6549-54. Crossref PMid:7896791

43. Davis KA, Miyares MA. Lomitapide: A novel agent for the treatment of homozygous familial hypercholesterolemia. Am J Health Syst Pharm. 2014; 71(12):1001-8. Crossref PMid:24865757

44. Zimmerman MP. How do PCSK9 inhibitors stack up to statins for low-density lipoprotein cholesterol control? American Health and Drug Benefits. 2015; 8(8):436-42. PMid:26702335 PMCid:PMC4684634

45. Paton DM. PCSK9 inhibitors: Monoclonal antibodies for the treatment of hypercholesterolemia. Drugs Today (Barc). 2016; 52(3):183-92. Crossref PMid:27186592

46. Chaudhary R, Garg J, Shah N, Sumner A. PCSK9 inhibitors: A new era of lipid lowering therapy. World J Cardiol.2017; 9(2):76-91. Crossref PMid:28289523 PMCid:PMC5329749

47. Burke AC, Dron JS, Hegele RA, Huff MW. PCSK9: Regulation and target for drug development for dyslipidemia. Annu Rev Pharmacol Toxico. 2017; 57:223-44. Crossref PMid:27575716 